\title{
Lipids as indicators of paleoclimatic changes, II: Terrestrial biomarkers
}

\author{
Luiz A. S. Madureira \& Alexandre Piccinini
}

\author{
Departamento de Química da Universidade Federal de Santa Catarina \\ (Campus Universitário Trindade, 88040900 Florianópolis, SC, Brasil)
}

- Abstract: Variations in the abundance of specific lipid biomarker compounds derived from terrestrial sources are shown to be closely related to past climatic changes. Despite biodegradation processes, which take place mostly at the water column and sediment water interface, these compounds are found well preserved in oceanic sediments. Here, their relative distribution is employed as a tool to assess changes in terrestrial fluxes to the seabed accompanying climatic variations during glacial and interglacial intervals. These changes in biomarker distribution were estimated in two sediment cores taken from the eastern North Atlantic, covering the past 210,000 years. Comparisons with other paleoclimate proxies showed good agreement and suggest that some specific groups of biomarkers are important indicators of changes in terrestrial inputs to the sea.

- Resumo: A variação na abundância de alguns biomarcadores lipídicos derivados de aportes terrestres pode estar relacionada com mudanças climáticas no passado. Apesar dos processos de biodegradação que, na grande maioria, ocorrem na coluna aquática e na interface sedimento-água, esses compostos são encontrados bem preservados em sedimentos oceânicos. Nesse trabalho, a distribuição relativa desses compostos é empregada como uma ferramenta para avaliar mudanças no transporte de material terrestre para o mar em paralelo às variações climáticas durante os intervalos glaciais e interglaciais. As mudanças na distribuição dos biomarcadores foram estimadas em dois testemunhos coletados ao leste do Atlântico Norte e que correspondem aos últimos 210 mil anos. Os resultados mostraram uma boa correlação entre a distribuição dos biomarcadores e outros parâmetros paleoclimáticos previamente avaliados nos perfis, sugerindo que alguns grupos específicos de compostos orgânicos são importantes indicadores de aporte terrestre para o mar.

- Descriptors: Biomarkers, Marine sediment, Chromatography, North Atlantic.

- Descritores: Biomarcadores, Sedimento marinho, Cromatografia, Atlântico Norte.

\section{Introduction}

\section{Marine and terrestrial biomarkers}

Lipid compounds found in deep sea sediments are mainly derived from marine and terrestrial sources. These organic compounds, known as biomarkers, are widely used as indicators of phytoplankton productivity or allochthonous sources. Some groups of biomarkers can also reveal key information about past productivity and climatic changes (Schneider $e t$ al., 1995; Madureira et al., 1997; Ohkouchi et al., 1997). Biomarkers may reach the seafloor unaltered or partially altered, so that it is still possible to interpret their occurrence in sediments in terms of input from a specific source. Groups of marine compounds, for example, phytosterols and the haptophyte-derived long-chain alkenones and alkyl alkenoates are important indicators of overlying surface water productivity and of phytoplankton species composition (Poynter et al., 1989; Farrimond et al., 1990; Madureira et al., 1995). Long-chain alkenones and alkyl alkenonates are also employed as a paleo sea surface temperature (SST) proxy, in stratigraphic records (Zhao et al., 1993 and 1995).

Among the terrestrial biomarkers, straight longchain $\left(>C_{20}\right)$ alkanes, alkanols and alkanoic acids are known as the major compounds derived from leaf waxes that may reach the deep sea floor. Their 
abundance and within-class distribution may be used to indicate inputs of land-derived material to the sediments (McCaffrey et al., 1991; Jasper and Gagosian, 1993; Madureira et al., 1995). In the North Atlantic, their transport to the open ocean is mainly associated with aerosols from Africa (Simoneit et al., 1977; Huang et al., 1993). However, it is common knowledge that some marine bacteria and algae may also contain such group of compounds, though with a distinct extent of even/odd predominance (Volkman et al., 1981).

In this work, we compared the biomarker data obtained for the sediment core T88-9P taken in 1988, whose results have previously been reported (van Kreveld, 1996; van Kreveld et al., 1996; Madureira et al., 1997), with core T90-2P taken in 1990 in the same region of the eastern North Atlantic (Fig. 1). The same sampling intervals were used in both studies. In order to assess changes in terrigenous input to the seabed, the relative distribution and abundance of three lipid groups - alkanes $\left(\mathrm{C}_{27}, \mathrm{C}_{29}\right.$ and $\left.\mathrm{C}_{31}\right)$, alkanoic acids $\left(\mathrm{C}_{24}, \mathrm{C}_{26}\right.$ and $\left.\mathrm{C}_{28}\right)$, and alkanols $\left(\mathrm{C}_{24}, \mathrm{C}_{26}\right.$ and $\left.\mathrm{C}_{28}\right)$ - were analysed during glacial and interglacial intervals along the two piston cores collected, compiling approximately $210 \mathrm{ka}$ of sediment record.

\section{Transport of terrestrial material to the ocean}

Terrestrial material can be carried to the ocean via three main pathways: aeolian transport, fluvial discharges and, to a lesser extent, ice rafting. River runoff is the major vehicle by which terrestrial material is delivered to estuarine and coastal sediments (Chester, 1990). Land-derived organic matter carried to the ocean in rivers includes recently biosynthesised plant debris and dissolved humic substances, accompanied by older soil humus (Hedges et al., 1986). The average global discharge of river suspended and dissolved organic matter to the west African coast is about 258 million tons per year. In contrast, fluvial discharges in the eastern North Atlantic yield about 18 million tons annually (Chester, op. cit.). With respect to lipid compounds, river mouths have been examined and the results indicated significantly higher plant contributions to coastal waters (Farrington et al., 1988; McCaffrey et al., 1991). However, for open oceans it has become increasingly apparent that long-range atmospheric transport is an important route for the delivery of organic material to deep sea sediments (Simoneit, 1977; Simoneit et al., 1977; Gagosian et al., 1981). Atmospheric particles have been extensively studied off the coast of west Africa, particularly pollen (Hooghiemstra, 1989), mineral aerosols (Schultz and Quinn, 1972) and organic compounds (Simoneit,
1978; Huang et al., 1993), showing the importance of both surface and higher altitude zonal winds on the west African coast.

\section{Indices related to terrestrial inputs}

Several indices can be used to assess exogenous input to the sea. For instance, within-class distribution of long-chain $\left(>C_{20}\right)$ linear alkanes, alkanoic acids, and alkanols is often employed to infer terrestrial input into sediments. Carbon Preference Indices (CPI) based upon the odd/even preferences of these compounds were introduced over twenty years ago (Cooper and Bray, 1963; Kevenvolden, 1966) and, since then, have been extensively used to estimate the extent of land derived input into sediments in a great variety of environments (e.g. Gagosian et al., 1987; Venkatesan and Xaplan, 1987; Rieley et al., 1991). The typical CPI range for each of these three compound classes is $2-40$ (Rieley et al., op. cit.). High values of CPI with a clear terrestrial signature can also be found in aerosol samples, as documented by Simoneit (1978), Gagosian et al. (op. cit.), and Huang et al. (1993). Another index that has been widely used for computing the ratio of the relative concentrations of homologs is the odd/even predominance (OEP) introduced by Scalan and Smith (1970). In our samples, due to the low amounts of several hydrocarbons with even number of carbon atoms, we employed the OEP ratio instead of $\mathrm{CPI}$ to assess possible changes in terrestrial sources with core depth (Table 1). This ratio is less sensitive to the general trend in relative abundances but is a more sensitive measure of their local odd/even ratio.

Other indices have been introduced during the last ten years. For example, the Average Chain Length (ACL) index was proposed by Poynter and Eglinton (1990) to discriminate between terrestrial source regions of aerosol inputs from West Africa. This index has not shown clear variations when estimated using surface sediment samples taken in the eastern North Atlantic (Madureira, 1994). These authors also introduced the Alcohol Preservation Index (API), which was proposed in an attempt to measure to what extent alkanes and alkanols may be exposed to degradation while sinking through the water column. Therefore, this index is also associated with variation in the sedimentation rate. Lower values for this ratio should thus be found in sediments deposited in deeper waters, and greater values in shallower waters. We used API to investigate changes in degradation and sedimentation rates with depth in both cores (Table 1). 


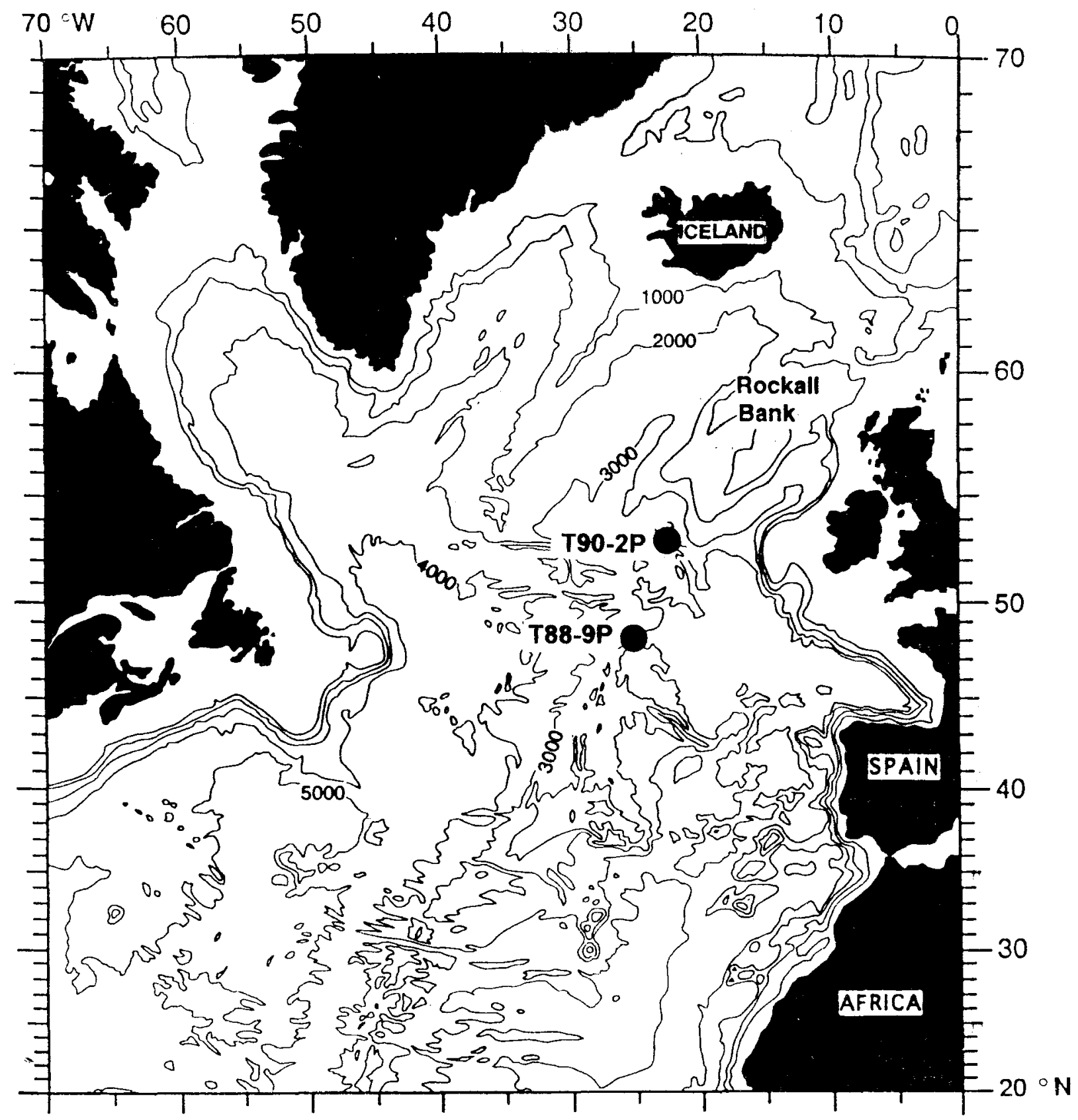

Fig. 1. Physiographic map with locations of both cores T88-9P (48 $23^{\prime} \mathrm{N}, 25^{\circ} 05^{\prime} \mathrm{W}$, water depth $3193 \mathrm{~m}, 790 \mathrm{~cm}$ long) and T902P $\left(52^{\circ} 23^{\prime} \mathrm{N}, 21^{\circ} 05^{\prime} \mathrm{W}\right.$, water depth $3200 \mathrm{~m}, 900 \mathrm{~cm}$ long) in the Northeast Atlantic (redrawn from Uchupi, 1971). Core T88-9P was taken on the rising east flank of the Mid-Atlantic Ridge. Core T90-2P was recovered south of the Rockall Plateau. 
Table 1. Estimated Alcohol Preservation Index (API) to cores T88-9P and T90-2P and Odd-Even Preference Index (OEP) to core T90-2P during Holocene and Last Glacial intervals.

\begin{tabular}{ccccc}
\hline Period & $\begin{array}{c}\text { Depth } \\
(\mathrm{cm})\end{array}$ & $\begin{array}{c}\text { API } \\
\text { (T88-9P) }\end{array}$ & $\begin{array}{c}\text { API } \\
(\text { T90-2P) }\end{array}$ & $\begin{array}{c}\text { OEP } \\
(\text { T90-2P) }\end{array}$ \\
\hline \multirow{6}{*}{ Holocene } & 10 & 0.54 & 0.62 & 0.57 \\
& 15 & 0.56 & 0.50 & 0.51 \\
& 20 & 0.57 & 0.52 & 0.51 \\
& 30 & 0.58 & 0.44 & 0.49 \\
& 35 & 0.63 & 0.41 & 0.44 \\
Last & 40 & 0.63 & 0.52 & 0.47 \\
\hline \multirow{3}{*}{ Glacial } & 50 & 0.61 & 0.54 & 0.32 \\
& 60 & 0.55 & 0.50 & 0.21 \\
& 80 & 0.48 & 0.50 & 0.25 \\
& 90 & 0.58 & 0.41 & 0.22 \\
& 246 & 0.59 & 0.21 & 0.24 \\
& 260 & 0.58 & 0.62 & 0.24 \\
& & 0.67 & 0.47 & 0.21 \\
\hline
\end{tabular}

CV $<15 \%(n=3)$ for each depth interval of $2.5 \mathrm{~cm}$.

$A P I=\left(C_{24}+C_{25}+C_{28}\right.$ alkanols $) /\left(C_{24}+C_{26}+C_{28}\right.$ alkanols $)+\left(C_{27}+C_{28}+C_{31}\right.$ alkanes $)$ (Poynter \& Eglinton, 1990).

$\mathrm{OEP}=\left[\left(\mathrm{C}_{27}+6 \times \mathrm{C}_{29}+\mathrm{C}_{31} \text { alkanes }\right) /\left(4 \times \mathrm{C}_{28}+4 \times \mathrm{C}_{30} \text { alkanes }\right)\right]^{-1} \quad$ (Scalan \& Smith, 1970)

Ratios of alkanols and alkanes determined from corrected peak areas of gas chromatograms.

In addition to the indices described above, other ratios based on hydrocarbon, alkanol, and fatty acid distribution are widely used to investigate diagenesis, relative contribution of marine versus terrigenous sources of organic matter, and alteration processes taking place at oxic-anoxic interface (e.g. Meyers et al., 1980; Wakeham \& Beier, 1991; Bourbonniere \& Meyers, 1996). In order to assess possible changes in aquatic-terrigenous contributions over the glacial/interglacial periods, we used a ratio based on the abundance of the alkanoic acid $\mathrm{C}_{16}$ to the hydrocarbon $\mathrm{C}_{29}$ (marine/terrestrial ratio). Shortchain fatty acids $\left(\mathrm{C}_{12}, \mathrm{C}_{14}\right.$, and $\left.\mathrm{C}_{16}\right)$ are mainly produced by marine organisms (Cranwell et al., 1987) and the long-chain hydrocarbons are found in epicuticular waxes of land-plants (Rieley et al., 1991)

\section{Materials and methods}

For both eores, sediment sub-samples were taken every $5 \mathrm{~cm}$ frow the upper $50 \mathrm{~cm}$, and then at about $10 \mathrm{~cm}$ intervals for the rest of the core. Samples were also taken at high resolution $(2.5 \mathrm{~cm}$ intervals, approx. 500 years) across glacial-interglacial transitions (Terminations I and II), which have strong gradients in $\delta^{18} \mathcal{O}$ and microfossil species composition. The depth intervals analysed for $t$ restrial biomarkers were the same as those for sedimentological analyses described in van Kreveld et al. (1996). The extraction technique and sediment analyses for T90-2P by GC and GC-MS followed the same procedure as for T88-9P, and details are given in Madureira et al. (1995 and 1997). Briefly, prior to analysis, porewater was removed by evaporation/freeze-drying and the dried sediment homogenised in a mortär and pestle. An internal standard mixture $\left(\mathrm{C}_{36} n\right.$-alkane, cholestane, and $\mathrm{C}_{23: 1}$ fatty acid) was added before extraction. Lipids were extracted in 1:1 $\mathrm{CH}_{2} \mathrm{Cl}_{2}: \mathrm{CH}_{3} \mathrm{OH}(2 \mathrm{x})$ and $\mathrm{CH}_{2} \mathrm{Cl}_{2}$ (1x), using a solvent/sediment ratio of 3:1. The lipid extract was transesterified under $\mathrm{N}_{2}$ using anhydrous $5 \%$ methanolic $\mathrm{HCl}$ in toluene. The samples were then trimethylsilylated using BSTFA prior to GC and GC-MS analyses. Gas chromatography was carried out using a model 17A Shimadzu GC, using a $30 \mathrm{~m}$ $\mathrm{x} 0.25 \mathrm{~mm}, 0.25 \mu \mathrm{m}$ film thickness, CBP1 column. The temperature programme was $50-180^{\circ} \mathrm{C}$ at $10^{\circ} \mathrm{C}$ $\min ^{-1}$ and $180-310^{\circ} \mathrm{C}$ (holding for $20 \mathrm{~min}$ ) at $4^{\circ} \mathrm{C}$ $\min ^{-1} . \mathrm{N}_{2}$ was used as a carrier gas. GC-MS analyses (EI mode, $70 \mathrm{eV}$ ) were carried out on a QP-2000A mass spectrometer interfaced to a model 14B Shimadzu GC. Conditions for GC-MS analyses were as for $\mathrm{GC}$ except that $\mathrm{He}$ was used as carrier gas. It is important to mention that the T90-2P core was fully extracted and the total lipids analysed at the Chemistry Department of Santa Catarina University, whereas the T88-9P extraction and analysis were carried out at the Biogeochemistry Centre of Geology Department, Bristol University.

The ages shown outside the panels in Figures 2 and 3 are based on three radiocarbon dates, two ash layers and the correlation of the oxygen isotope curves of the planktic foraminiferal Globigerina bulloides and Globorotalia inflata with the chronostratigraphy of Martinson et al. (1987) and van Kreveld et al. (1996). These ages were not determined to core T90-2P. The isotopic stage intervals in T90-2P were estimated on the basis of the $\delta^{18} \mathrm{O}$ of Globigerina bulloides variation with depth. Analyses of Globigerina bulloides specimens in the T90-2P core were performed at the Centre for Marine Earth Sciences, Institute of Earth Sciences, Free University. The foraminiferal tests were ultrasonically cleaned for 1 to 2 minutes in analytical grade methanol and then acidified with $100 \% \mathrm{H}_{3} \mathrm{PO}_{4}$ in vacuum at $50 \pm 0.5^{\circ} \mathrm{C}$. The released $\mathrm{CO}_{2}$ gas was analysed offline with a Finnigan MAT 251 mass spectrometer. All isotopic values are given in the " $\delta$ " notation in parts per thousand (\%) and expressed relative to the PDB standard (further details are given in van Kreveld, 1996).

For core T90-2P, a total of 97 bulk samples were analysed in duplicate for weight \% carbonate using a Scheibler-type gasometric technique with a $\pm 2 \%$ precision. Duplicate measurements for organic carbon content of 49 bulk samples were carried out in a Carlo Erba NA-1500 elemental analyser and followed the procedure described in van Kreveld (1996). Both cores provided good carbonate production records since they lie above the lysocline and are recovered from an open-ocean environment where coccolithophorid blooms presently occur and where foraminifera are abundant. 

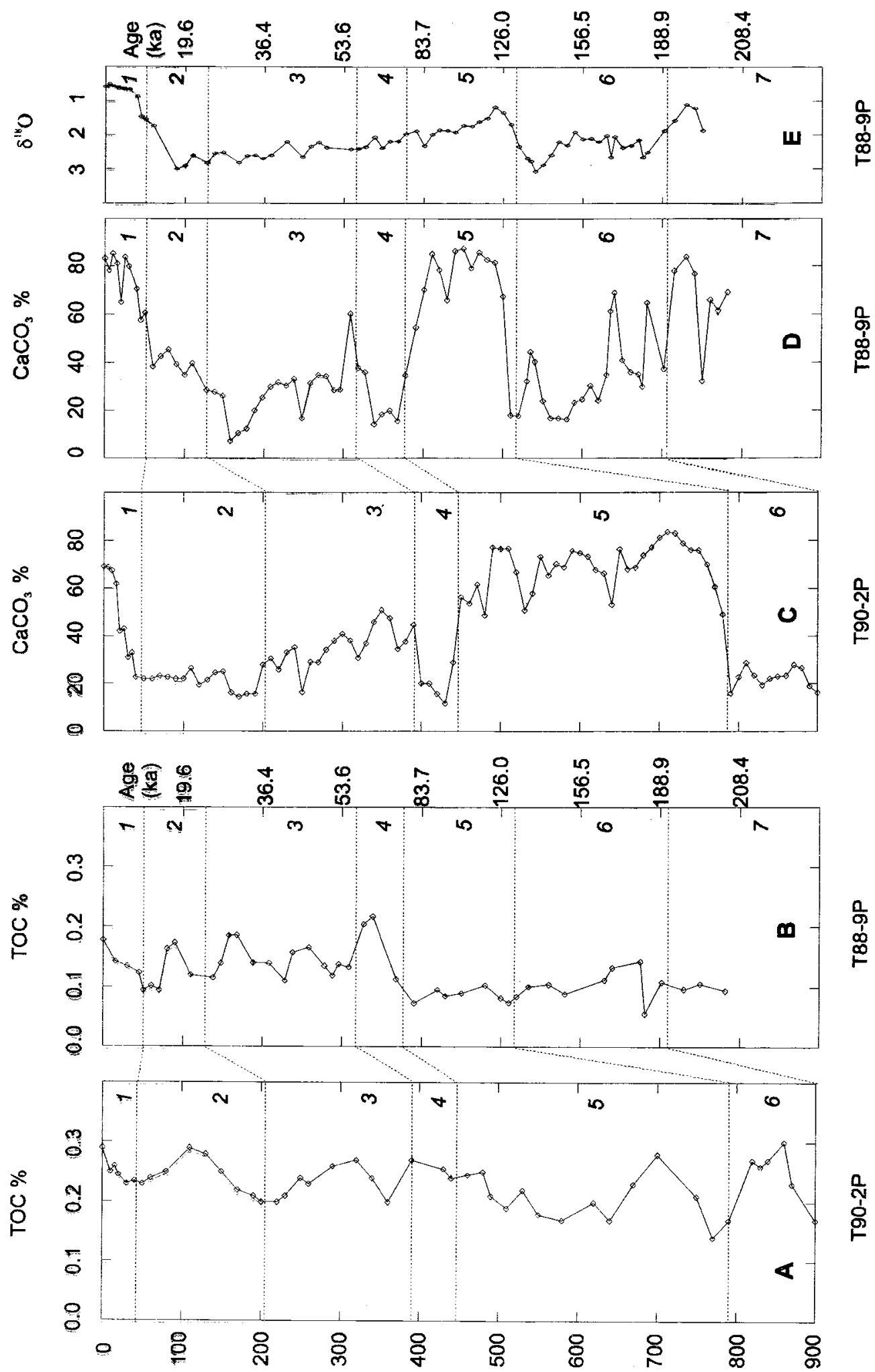

(us) 4 deg

Fig. 2. Downcore prefles in T90-2P and T88-9P cores, respectively, of: weight percentages of total organic carbon, TOC \% (A) and (B); \% $\mathrm{CaCO}_{3}$ of fine fraction $(<32 \mu \mathrm{m})$ of sediment (C) and (D). The data shown here for oxygen isotopic ratio in Globigerina bulloides was estimated to core T88-9P (E) (van Kreveld, 1996). Numbers inside of panels indicate isotopic stages. Ages shown here were only determined to T88-9P core $(\mathrm{ka}=$ thousand years). 

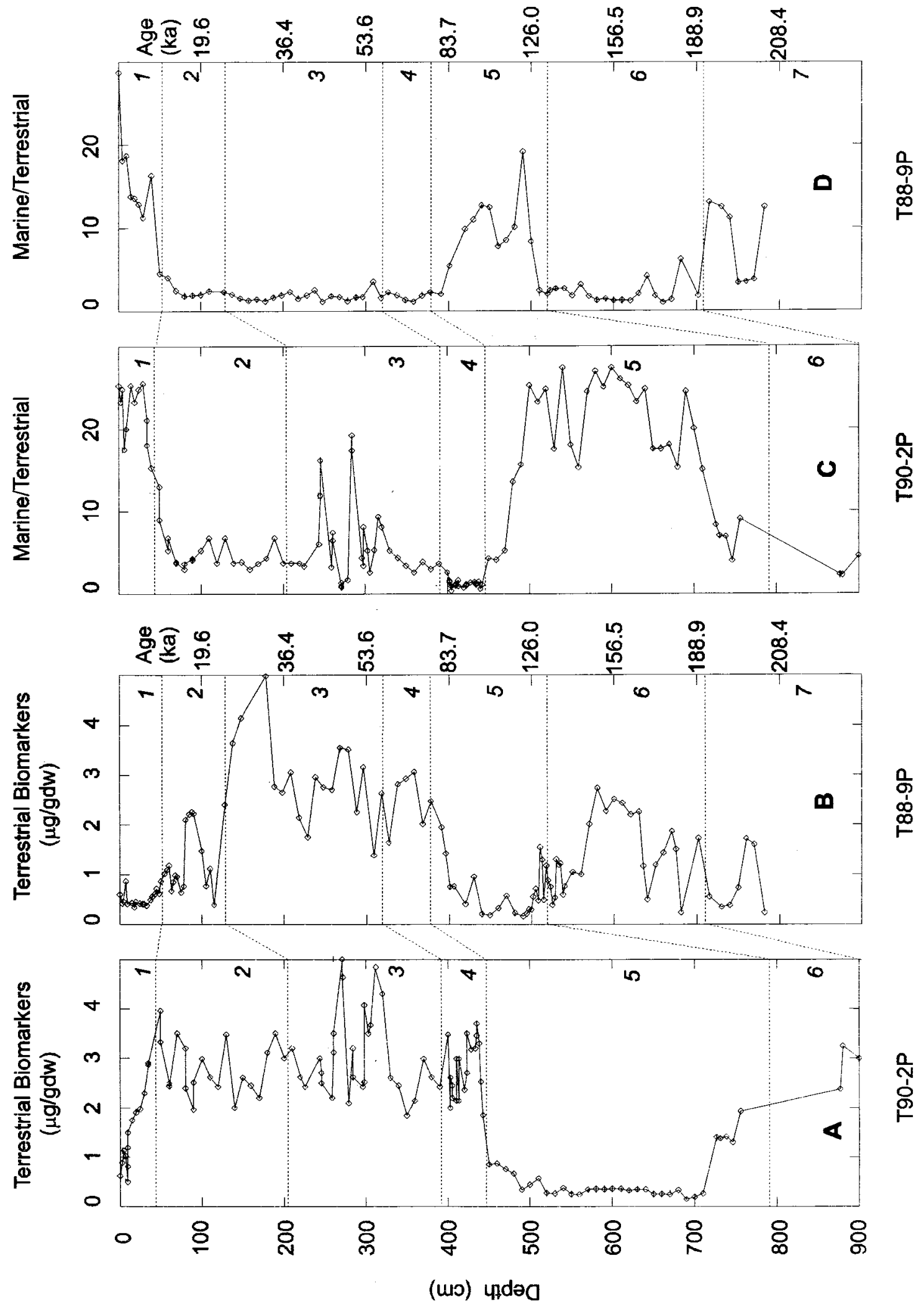

Fig. 3. Downcore profiles in T90-2P and T88-9P cores, respectively, of: sum of terrestrial biomarkers (alkanes $\mathrm{C}_{27}, \mathrm{C}_{29}, \mathrm{C}_{31}$; alkanoic acids and alkanols $\mathrm{C}_{24}, \mathrm{C}_{26}, \mathrm{C}_{28}$ - concentrations in $\mu \mathrm{g} / \mathrm{gram}$ of dry weight) (A) and (B); marine (hexadecanoic acid $\mathrm{C}_{16}$ ) / terrestrial (hydrocarbon $\mathrm{C}_{29}$ ) ratio (C) and (D). Numbers inside of panels indicate isotopic stages. Ages shown here were only determined to T88-9P core $(\mathrm{ka}=$ thousand years $)$. 


\section{Results and discussion}

\section{Bulk parameters}

Downcore profiles of total organic carbon (\% TOC) varied little with depth at both sites. Most TOC values fell between 0.10 and $0.30 \%$, with average values for TOC slightly higher for core T902P $(0.25 \%$; Fig. 2A) than for core T88-9P $(0.12 \%$; Fig. 2B). These low TOC values were consistent with those of other abyssal sediments measured at nearby stations (Brand \& Shimmield, 1992; Santos et al., 1994; Madureira et al., 1995; Manighetti and McCave, 1995; Villanueva et al., 1997). In core T90$2 \mathrm{P}$, TOC values showed no trend along the glacialinterglacial intervals. A clear variation is only seen for core T88-9P, particularly in the transition of isotopic stages $5-4$, where TOC increased from 0.07 to $0.2 \%$. In Villanueva et al. (op. cit.), TOC measurements in two cores taken from the North Atlantic also indicated that higher TOC values can be found during glacial periods and lower values during interglacials. According to these authors, most of the TOC present in glacial sediments is of detrital origin, which is a clear indication of higher terrestrial input. As we will discuss later, higher TOC values are associated with higher amounts of terrestrial biomarkes. In contrast with the slight changes of \% TOC during the glacial-interglacial transitions, in both cores $\% \mathrm{CaCO}_{3}$ varied quite remarkably in parallel with glacial-interglacial changes in climatic conditions (Fig. 2C and 2D). Values shown here are from the fine carbonate fraction $(<32 \mu \mathrm{m})$, which is mainly composed of coccoliths and detrital carbonate with minor contribution from juveniles and fragments of foraminifera (van Kreveld, 1996). Such changes suggest that this carbonate fraction is an important indicator of marine paleo primary productivity for glacial and interglacial intervals. In fact, the boundaries between isotopic stages $6-5,5-4$, and $2-1$ are marked by clear changes in the $\% \mathrm{CaCO}_{3}$. In both sites carbonate increased nearly $50 \%$ from the penultimate glacial period (isotopic stage 6) to the last interglacial period (isotopic stage 5). These values remained relatively high along the interglacial interval and began to fall again at the end of this warm period. During the last glacial interval, data from both sites showed that $\mathrm{CaCO}_{3}$ averaged nearly $30 \%$ and only increased again at the beginning of the present interglacial interval (isotopic transition stage 2 - stage 1). The results seen here for the glacial stage are consistent with $\% \mathrm{CaCO}_{3}$ contents found in the Atlantic Ocean bottom sediments during the Last Glacial Maximum (Balsam and McCoy, 1987). Working on T88-9P core, van Kreveld et al. (1996) showed that paleo primary productivity estimates based on biogenic carbonate accumulation rates are generally higher during interglacial periods than in ambient glacials. These authors also identified changes in $\% \mathrm{CaCO}_{3}$ at depth intervals associated with the Heinrich events (see discussion about those events in van Kreveld et al., 1996 and Madureira et al., 1997). Here, the results for both cores stress the importance of fine fraction carbonate as a paleo primary productivity proxy in open ocean sediments dominated by $\mathrm{CaCO}_{3}$ tests. However, it is important to mention that, apart from changes in sea surface productivity, variability in carbonate contents may result from other factors such as water depth, transport of carbonate material from other areas, and dilution from terrigenous sources (Balsam \& McCoy, 1987). For the Atlantic Ocean sediments, water depth is the primary control, as below a certain depth waters become undersaturated in carbonate. Over much of the Atlantic Ocean, the calcium carbonate compensation depth ranges from ca. $4.5-5.0 \mathrm{~km}$. At greater depths, dissolution exceeds supply and there is no accumulation of significant amounts of carbonate material. Nevertheless, none of the sites studied here were deeper than $4500 \mathrm{~m}$; thus, water depth does not seem to be a major factor. However, the other two factors mentioned above could be, to some extent, accountable for carbonate shifts. But the sharp carbonate changes following climatic transitions is a strong evidence of sea surface productivity predominance.

\section{Downcore biomarker profiles}

Madureira et al. (1997) compared the sum of molecular biomarker and sedimentological data for selected depth intervals of isotopic stages $1-6$ for core T88-9P. In agreement with previous findings (Madureira et al., op. cit.), the results shown here for T90-2P confirmed that glacial stages ( $2-4$ and 6$)$ are richer in molecular compounds compared to interglacial stages (Figs 3A and 3B). The molecular based parameter (marine/terrestrial ratio) estimated for both cores showed clear variations with climatic periods (Figs 3C and 3D). This ratio was nearly five times higher for isotopic stages 1 and 5 than for glacial intervals. Such results suggest that interglacial intervals are accompanied by a higher input of marine compounds or that the relative decrease in terrigenous organic matter influx during interglacial intervals could be accountable for the rise in the marine/terrestrial ratio. Figures $3 \mathrm{~A}$ and $3 \mathrm{~B}$ seem to support the later statement, as the sum of terrestrial biomarker compounds (alkanes $\mathrm{C}_{27}, \mathrm{C}_{29}$, and $\mathrm{C}_{31}$; alkanoic acids and alkanols $\mathrm{C}_{24}, \mathrm{C}_{26}$, and $\mathrm{C}_{28}$ ) was less than one during stages 1 and 5 . Our 
data agree with the results found in cores SU90/08 and SU90/39, where changes in marine TOC were shown to be independent of glacial-interglacial changes (Villanueva et al., 1997). Unlike marine signals, terrigenous biomarkers showed clear variations in both cores, T90-2P and T88-9P, accompanying climatic changes. However, it is interesting to note that during stage 2 concentrations of terrestrial biomarkers are higher in core T90-2P than T88-9P. This specific feature suggests that in core T90-2P there is a higher contribution of icerafted material during this stage, which is consistent with its location, further north than core T88-9P. Significant contributions of terrigenous compounds were also observed in cores SU08/39 and SU90/39 in which alkanes were used to assess continental contributions to organic matter (Villanueva et al., op. cit.).

Land derived material is thought to be brought to the open ocean mainly by ice raft, particularly in latitudes higher than $40^{\circ} \mathrm{N}$, and to a lesser extent by eolian transport. However, we have recently pointed out that dust material is an important source of exogenous organic matter even in latitudes higher than $40^{\circ} \mathrm{N}$ (Madureira et al., 1997). Profiles of ion contents originating from aerosols trapped in an ice core from east Antarctica showed that terrestrial aerosol inputs were higher during cold climatic conditions than during the last interglacial and Holocene stages (Legrand et al., 1988; GRIP, 1993). Thus, contributions from eolian dust to marine sediments are also important, and part of the icetransported material may in fact be dust deposited in ice sheets. Legrand et al. (op. cit.) used aluminium to show that the increase in inorganic material found trapped in ice cores during glacial intervals could be related to the expansion of arid areas, and that stronger emissions would occur due to increased wind speed over the continents.

A comparison of $\% \mathrm{CaCO}_{3}$ profiles in T88-9P and T90-2P showed good correlation between the carbonate signal and marine/terrestrial changes over glacial-interglacial periods. The plot of $\% \mathrm{CaCO}_{3}$ versus marine/terrestrial ratio summarises this relationship (Fig. 4). Accordingly, high ratio values were found to be related to high $\% \mathrm{CaCO}_{3}$ values and they are associated with interglacial stages. In contrast, low ratio values were found to be related to low $\% \mathrm{CaCO}_{3}$ contents. However, it is important to mention that changes in the marine/terrestrial ratio found in this work seem to be more dependent on variations in the abundance of terrestrial compounds than of marine ones.

The OEP ratio was estimated for a few depth sections in core T90-2P over the last glacial and the present interglacial intervals (Table 1). It is interesting to note the low OEP values during the last glacial and their slight increase toward the Holocene. Distribution of alkanes without odd/even predominance can be attributed to microbial reworking of the odd $\mathrm{C}$-numbered alkane mixtures (Grimalt et al., 1985; 1986). Thus, such shift in OEP values suggest that the terrestrial biomarkers deposited during those periods may have had distinct origins or that during the glacial period the detrital material deposited was more reworked. Unlike OEP, the API index did not show any trend with depth. It is difficult to establish a clear relationship between oscillations in API values in both sites and either water depth or sedimentation rate. API values could result from a combination of changes involving both parameters.

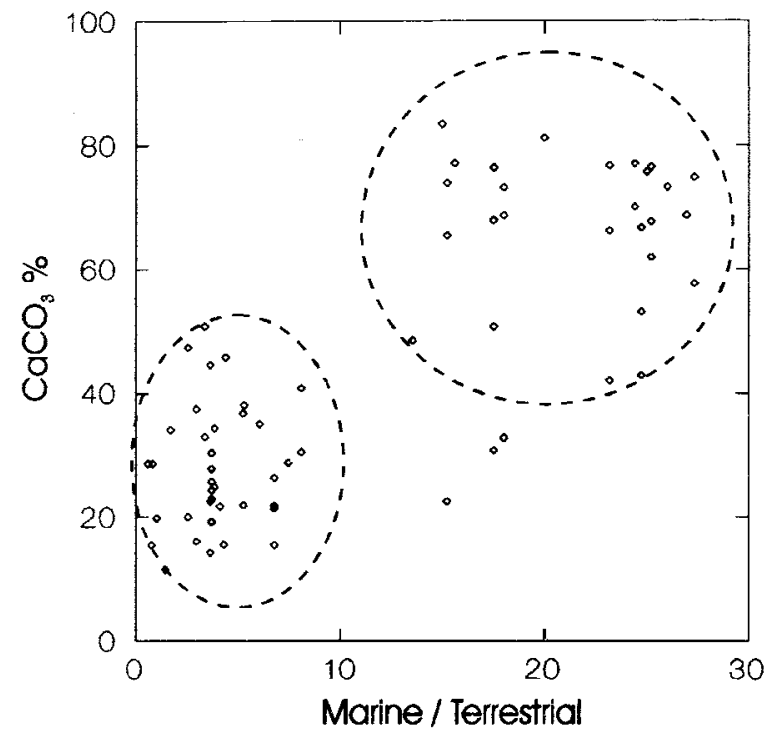

Fig. 4. Core T90-2P plot of $\% \mathrm{CaCO}_{3}$ of fine fraction $(<32$ $\mu \mathrm{m})$ versus marine / terrestrial ratio (hexadecanoic acid $\mathrm{C}_{16}$ / hydrocarbon $\mathrm{C}_{29}$ ).

\section{Conclusions}

As we have already mentioned, biomarker compounds have been widely reported to be a valuable tool to assess terrigenous and marine signatures in the sediment record. They can be used with inorganic indicators for paleoceanographic interpretations. Changes in terrigenous inputs to the oceans associated with earth climatic cycles are well documented by some biomarker compounds. Here, we have showed that during glacial stages the extractable fraction of organic matter and TOC are mainly related to terrestrial signatures. However, using some planktonic derived organic compounds, the marine signal observed here was not so evident. Those compounds did not show significant changes 
with climatic variations. In fact, the only proxy that showed clear changes was the fine fraction of calcium carbonate analysed in both cores.

Due to the position of T88-9P and T90-2P in the Northeast Atlantic, terrigenous organic matter is believed to be brought mainly by ice raft. However, eolian input cannot be ruled out, and during glacial stages it may have been an additional source of land derived material.

\section{Acknowledgements}

We thank Dr. Shirley A. van Kreveld, Dr. Janneke J. Ottens, Dr. G. Ganssen, and Dr. J. E. van Hinte for the bulk parameters and sediment samples provided. Luiz Madureira thanks CNPq for a postdoctoral scholarship and Alexandre Piccinini thanks PIBIC-UFSC for an undergraduate scholarship.

\section{References}

Balsam, W. L. \& McCoy Jr., F. W. 1987. Atlantic sediments: glacial/interglacial comparisons. Paleoceanography, 5:531-542.

Bourbonniere, R. A. \& Meyers, P. A. 1996. Sedimentary geolipid records of historical changes in the watersheds and productivities of Lakes Ontario and Erie. Limnol. Oceanogr., 41(2):352-359.

Brand, T. \& Shimmield, G. 1992. The use of ${ }^{210} \mathrm{~Pb}$ as an indicator of biological processes affecting the flux and sediment geochemistry of organic carbon in the North East Atlantic. In: Kershaw, P.J. \& Woodhead, D.F. eds Radionuclides in the study of marine processes. New York, Elsevier. p.222233.

Chester, R. 1990. Marine geochemistry 1. Oceans, chemical composition \& chemical properties. London, Unwin Hyman Ltd. 698p.

Conte, M. H.; Volkman, J. K. \& Eglinton, G. 1994. Lipid biomarkers of the Haptophyta. In: Leadbeater, B. \& Green, J.C. eds The Haptophyte algae. Oxford, Claredon Press. p.351-377.

Cooper, J. E. \& Bray, E. E. 1963. A postulated role of fatty acids in petroleum formation. Geochim. cosmochim. Acta, 27:1113-1127.
Cranwell, P. A.; Eglinton, G. \& Robinson, N. 1987. Lipids of aquatic organisms as potential contributors to lacustrine sediments. 2. Org. Geochem., 11(6):513-527.

Farrimond, P.; Poynter, J. \& Eglinton, G. 1990. A molecular stratigraphic study of Peru margin sediments, Hole 686B, Leg 112. In: Suess, E. \& von Huene eds. Proceedings of the ocean drilling program. scientific results. 547-553.

Farrington, J. W.; Davis, A. C.; Sulanowski, J.; McCaffrey, M. A.; McCarthy, M.; Clifford, C. H.; Dickinson, P. \& Volkman, J. K. 1988. Biogeochemistry of lipids in surface sediments of the Peru upwelling area at $15^{\circ} \mathrm{S}$. Org. Geochem., 13(4-6):607-617.

Gagosian, R. B.; Peltzer, E. T. \& Zafiriou, O. C. 1981. Atmospheric transport of continentallyderived lipids to the tropical North Pacific. Nature, 291(5813):312-314.

Gagosian, R. B.; Peltzer, E. T. \& Merril, J. T. 1987. Long-range transport of terrestrially derived lipids in aerosols from the South Pacific. Nature, 325(6107):800-804.

Grimalt, J. O.; Albaigés, J.; Douabul, A. A. Z. \& AlSaad, H. T. 1985. n-Alkane distributions in surface sediments from the Arabian Gulf. Naturwissenschaft, 72(1):35-37.

Grimalt, J. O.; Albaigés, J.; Alexander, G. \& Hazai, I. 1986. Predominance of even carbon numbered alkanes in coal seam samples of Nograd basin (Hungary). Naturwissenschaft., 73(12):729-731.

GRIP Members. Greeland Ice-core Project (GRIP) Members. 1993. Climate instability during the last interglacial period recorded in the GRIP ice core. Nature, 364(6434):203-207.

Hedges, J. I.; Clark, W. A.; Quay, P. D.; Richey, J. E.; Devol, A. H. \& Santos, U. de M. 1986. Compositions and fluxes of particulate organic material in the Amazon River. Limnol. Oceanogr., 31(4):717-738.

Hooghiemstra, H. 1989. Variations of the NW African trade wind regime during the last 140000 years: changes in pollen flux evidenced by marine sediment records. In: Leinen, M. \& Sarnthein, M. eds Paleoclimatology and paleometeorology: modern and past patterns of global atmospheric transport. Boston, Kluwer Academic Publishers. p.733-770. 
Huang, Y.; Collister, J. W.; Chester, R. \& Eglinton, G. 1993. Molecular and $\delta^{13} \mathrm{C}$ mapping of aeolian input of organic compounds into marine sediments in the Northeastern Atlantic. In: INTERNATIONAL MEETING ON ORGANIC GEOCHEMISTRY, 16. Stavanger, Norway, 1993. Poster sessions. Norway, Falch Hurtigtrykk. p.523-528.

Jasper, J. P. \& Gagosian, R. B. 1993. The relationships between sedimentary organiccarbon isotopic composition and organic biomarker compound concentration. Geochim. Cosmochim. Acta, 57(1):167-186.

Kevenvolden, K. A. 1966. Molecular distributions of normal fatty acids and parafins in some lower cretaceous sediments. Nature, 209:573-577.

Legrand, M. R.; Lorius, C.; Barkov, N. I. \& Petrov. V. N. 1988. Vostok (Antarctica) ice core: atmospheric chemistry changes over the last climatic cycle ( 160,000 years). Atmos. Environ., 22(2):317-331.

Madureira, L. A. S. 1994. Lipids in recent sediments of the eastern North Atlantic. Tese de doutorado. University of Bristol. 246p.

Madureira, L. A. S.; Conte, M. H. \& Eglinton, G. 1995. Early diagenesis of lipid biomarker compounds in North Atlantic sediments. Paleoceanography, 10(3):627-642.

Madureira, L. A. S. 1997. Lipídios como indicadores de mudanças climáticas no passado 1: biomarcadores marinhos. Química Nova, 20(3):293-299.

Madureira, L. A. S.; van Kreveld, S. A.; Eglinton, G.; Conte, M. H.; Gassen, G.; van Hinte, J. E. \& Ottens, J. J. 1997. Late Quaternary highresolution biomarker and other sedimentary climate proxies in a northeast Atlantic core. Paleoceanography, 12(2):255-269.

Manighetti, B. \& McCave, I. N. 1995. Depositional fluxes, palaeoproductivity, and ice rafting in the NE Atlantic over the past 30 ka. Paleoceanography, 10(3):579-592.

Martinson, D. G.; Pisias, N. G.; Hays, J. D.; Imbrie, J.; Moore Jr., T. C. \& Shackleton, N. J. 1987. Age dating and the orbital theory of the ice ages: development of a high-resolution 0 to 300,000 year chronostratigraphy. Quat. Res., 27(1):1-29.
McCaffrey, M. A.; Farrington, J. W. \& Repeta, D. J. 1991. The organic geochemistry of Peru margin surface sediments II. Paleoenvironmental implications of hydrocarbon and alcohol profiles. Geochim. cosmochim. Actâ, 55(2):483-498.

Meyers, P. A.; Bourbonniere, R. A. \& Takeuchi, N. 1980. Hydrocarbons and fatty acids in two cores of Lake Huron sediments. Geochim. cosmochim. Acta, 44(8): 1215-1221.

Ohkouchi, N.; Kawamura, K. \& Taira, A. 1997. Fluctuations of terrestrial and marine biomarkers in the western tropical Pacific during the last 23,300 years. Paleoceanography, 12(4):623-630.

Poynter, J. \& Eglinton, G. 1990. Molecular composition of three sediments from hole $717 \mathrm{C}$ : the Bengal Fan. Proceedings of the Ocean Drilling Program. Scientific Results, 116:155161.

Rieley, G.; Collier, R. J.; Jones, D. M. \&. Eglinton, G. 1991. The biogeochemistry of Ellesmere Lake, UK - I: source correlation of leaf wax inputs to the sedimentary lipid record. Org. Geochem., 17(6):901-912.

Santos, V.; Billet, D. S. M.; Rice, A. L. \& Wolff, G. A. 1994. Organic matter in deep sea sediments from the Porcupine abyssal plain in the northeast Atlantic Ocean I. Lipids. Deep Sea Res., 41(5-6):787-819.

Scalan, R. S. \& Smith, J. E. 1970. An improved measure of the odd-even predominance in the normal alkanes of sediment extracts and petroleum. Geochim. cosmochim. Acta, 34:611620.

Schneider, R. R.; Müller, P. J. \& Ruhland, G. 1995. Late Quaternary surface circulations in the east equatorial South Atlantic: Evidence from alkenone sea surface temperatures. Paleoceanography, 10(2):197-219.

Simoneit, B. R. T. 1977. Organic matter in eolian dust over the Atlantic Ocean. Mar. Chem., 5(4-6):443-464.

Simoneit, B. R. T.; Chester, R. \& Eglinton, G. 1977. Biogenic lipids in particulates from lower atmosphere over the eastern Atlantic. Nature, 267(5613):682-685. 
Simoneit, B. R. T. 1978. The organic chemistry of marine sediments. In: Riley, J.P. \& Chester, R. eds Chemical oceanography. London, Academic Press. v.7 p. 233-311.

Schultz, D. M. \& Quinn, J. G. 1972. Fatty acids in surface particulate matter from the North Atlantic. J. Fish. Res. Bd Can., 29:1482-1486.

Uchupi, E. 1971. Bathymetric atlas of the Atlantic, Caribbean, and Gulf of Mexico. Woods Hole Oceanographic Institution, WHOI 71-72, unpublished manuscript.

van Kreveld, S. A.; Knappertsbusch, M.; Ottens, J. J.; Ganssen, G. \& van Hinte, J. E. 1996. Biogenic carbonate and ice-rafted debris (Heinrich layers) accumulation in deep sea sediments from a Northeast Atlantic piston core. Mar. Geol., 131(1-2):21-46.

van Kreveld, S. A. 1996. Late quaternary sediment records of mid-latitude Northeast Atlantic calcium carbonate production and dissolution. Tese de doutorado. Amsterdan, Free University. 212 p.

Venkatesan, M. I. \& Kaplan, I. R. 1987. The lipid geochemistry of Antarctic marine sediments: Bransfield Strait. Mar. Chem., 21(4):347-375.

Villanueva, J.; Grimalt, J. O.; Cortijo, E.; Vidal, L. \& Labeyrie, L. 1997. A biomarker approach to the organic matter deposited in the North Atlantic during the last climatic cycle. Geochim. cosmochim. Acta, 61(21):4633-4646.
Volkman, J. K.; Smith, D. J.; Eglinton, G.; Forsberg, T. E. V. \& Corner, E. D. S. 1981. Sterol and fatty acid composition of four marine Haptophycean algae. J. mar. biol. Ass. U.K., 61(2):509-527.

Wakeham, S. G. \& Beier, J. A. 1991. Fatty acid and sterol biomarkers as indicators of particulate matter source and alteration processes in the Black Sea. Deep-Sea Res., 38 (Suppl.2): S943S968.

Zhao, M.; Roseil-Melé, A. \& Eglinton, G. 1993. Comparison of two Uk37 sea surface temperature records for the last climatic cycle at ODP site 658 from the subtropical Northeast Atlantic. Palaeogeogr. Palaeoclimatol. Palaeoecol., 103:5765.

Zhao, M.; Beveridge, N. A. S.; Shackleton, N. J.; Sarnthein, M. \& Eglinton, G. 1995. Molecular stratigraphy of cores off northwest Africa: sea surface temperature history over the last $80 \mathrm{ka}$. Paleoceanography, 10(3):661-675.

(Manuscript received 06 July 1998; revised 30 August 1999; accepted 08 November 1999) 